\title{
КАЗАХСТАНЫ ТУСГААР ТОГТСОНЫ ДАРААХ УЕИЙН ШИНЖЛЭХ УХААН, ТЕХНИКИЙН ХӨГЖИЛ
}

М.Хурметхан *

Товч утга:

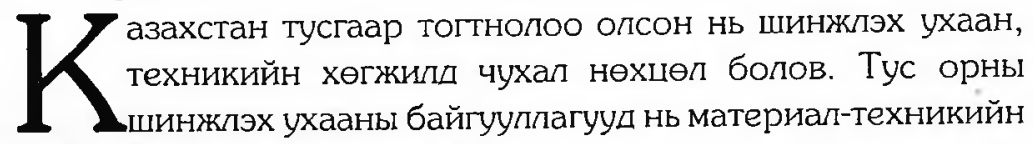
бааз, боловсон хүчин судлагааны далайцаар дэлхийн шинжлэх ухааны тэргуүпэх орнуудын түвшинд тун ойрхон очсон байлаа. Гэтэл 1990-ээд онд тохиолдсон эдийн засгийн өөрчлөлтөд шинжлэх ухаан, шинжлэх ухааны байгууплагууд хүчтэй нэрвэгдэв. Иймд, шинжлэх ухааны салбарт өөрчлөпт шинэчпэлт хийх нь зайлшгүй амин чухал асуудал болон гарч ирэв. Казахстаны тусгаар тогтнолын жилүудэд шинжлэх ухааны салбарт хийсэн өөрчлөлт шинэчпэлийн явцыг уг өгуүпэпд дэпгэрэнгуй өгүулэв. Шинжлэх ухааны хөгжлийН чанарын шинэ шатанд гарахад томоохон зарчмын алхмууд хийснээр тус орны шинжлэх ухааны хөгжил дэлхийн түвшин руУ тэмүүпж буйг тусган өГУупжээ.

Tyпхуур yr: Казахстан, тусгаар тогтонол, шинжлэх ухаан, хөгжил

\section{Казахстаны шинжлэх ухаан 1991-1996 онуудад}

Бүгд Найрамдах Казахстан улс нь хуучин $3 Х У$-аaс суурь шинжлэх ухааны хөгжингуй бааз болон бүрэлдэн тогтсон шинжлэх ухааны байгууллагуудыг өвлөн авсан билээ. Тухайн цагт Казахстан шинжлэх ухааны хөгжлийн түвшингээрээ ОХУ, Украины дараа орж байв. Казахстаны нутаг дэвсгэрт хопбооны упсын эрх мэдпийн эрдэм шинжипгээний хүрээлэн бопон дээд сургуупиудыг оролцуулан судлагааны 279 байгууплага үйл ажилпагаа явуупж байлаа. ${ }^{1}$ Энэ үед Казахстаны шинжлэх ухааны байгууппагууд боловсон хүчний хангамж; нөөцөөр дэлхийн шинжлэх ухааны тэргүүпэх орнуудын түвшинд тун ойрхон очсон юм. Төмөрлөгийн судлал, боловсруулах,

\footnotetext{
${ }^{*}$ М.Хурметхан - Олон улс судпалын хүрээлэнгийн эрдэм шинжипгээний тэргуүпэх ажилтан доктор (Sc.D), профессор)
} 
уул уурхай, физик, математик, сансар судлал, хими, биохими хүний физиологи болон биологи, анаагах ухаан, газарзуй, ботаник, хөдөө аж ахуйн төрөл бурийн салбарт өөрийн бие даасан шинжлээ ухааны дэг сургууль бурэпдэн тогтсон байна. Эрдэм шинжилгээ, туршилт зохион бүгээх болон технологийн салбарын нийт мэргэжилтний тоо - 39.4 мянган хүн ${ }^{2}$ байсан бөгөөд эдгээрийн дунд 8,2 мянган хүн их, дээд сургуупьд багшлахын хамтаар эрдэм шинжилгээ, туршилт зохион бутээх сапбарт хавсран ажилпаж байв. Эрдэм шинжилгээ болон туршипт - зохион бүтээх технопогийг үндсэн үйл ажилгааны орон тооны 31.2 мянган судлаачид хийж гүйцэтгэж байв. ${ }^{3} 1990$ ээд оны эхээр тус упсад салбарын харьяалпын шинжлэх ухааны байгууппагын тоо ихээр нэмэгдсэн явдал нь Казахстаны нутаг дэвсгэрт үйл ажилпагаа явуупж байсан ЗХУ-ын үеийн холбооны мэдэлд байсан 98 томоохон шинжлэх ухаан, туршипт-зохион бүтээх болон технологийн байгууппага ба тэдгээрийн салбарыг Казахстаны эрх мэлэпд шилжуүпсэнтэй холбоотой байлаа. Түүнээс гадна Казахстанд 1991-1994 оны хооронд төрийн эрдэм шинжилгээний 29 байгууплага шинээр нэмэгдэн байгуупагдсан юм. Өөрөөр хэлбэл, 1994 оны эцэст БНКазУ-д эрдэм шинжипгээ, төсөл зохион бүтээх байгуулпагууд, их, дээд сургуулиудын нийт тоо 406 болов ${ }^{4}$. Тэдгээр байгууплагын 283 нь эрдэм шинжилгээ, судпагааны ажил гүйцэтгэж байсны дотор нь эрдэм шинжилгээний байгууплага 154, пээд сургууль 48, төсөл зохиох болон төсөл зохион бүтээх байгууплага 41, аж үйлдвэрийн хэсэг 18 болон бусал 22 байгуулпага хамрагдаж байв ${ }^{5}$.

1990-ээд онд тус улсад эдийн засгийн хямрал тохиолдож аж үйлдвэр, шинжлэх ухааны сапбарыг улсын төсвөөс санхуүжүүпэх хэмжээ багассан нь эрдэм шинжилгээ зохион бүтээх байгууплагууд болон шинжлэх ухаан техникийн сапбарт ажиплагсдын тоо эрс хорогдоход хүргэсэн байна. 1996 он гэхэд тус салбарт ажиллагсдын тоо нь 1991 онтой харьцуулахад бараг хоёр дахин буюу 40,88 мянга /26,63 мянган мэргэжиптэнг оролцуупаад/ байснаас 20,6 мянга /14,6 мянган мэргэжилтэн судлаачдыг оролцуулаад/ болтол буурсан. 1990 онд нийт 50,6 мянган хүн эрдэм шинжипгээ техникийн салбајт ажиппаж байсантай харьцуупвал 2,45 дахин хасагдсан ажээ ${ }^{6}$. Иймд тус улсын өмнө эдийн засаг, упс төрийн салбараас илүүтэйгээр шинжлэх ухааны сапбарт өөрчлюлт шинэчлэлт хийх нь зайлшгүй амин чухал асуудал болон дэвшигдэн гарч ирсэн байна. Тусгаар тогтносон төр улсын хувьд дэвшил хөгжил, зах зээлийн эдийн засгийн нөхцөлд шинжлэх ухааны салбарт хийх өөрчпөлт, 
шинэчлэлтийн гол зорилго нь шинжлэх ухааны хөгжлийг зах зээлийн нөхшөлд зохицуупах, эдийн засгийн шинэ механизмтай адил тэнцүу ур ашигтай харилцан үйлчлэх, эдийн засаг, нийгмийн хэрэгцээ шаардлагад зохицон ажиллах, бодлого уйл ажиллагааны механизмыг боловсруулах явдал байв. Тэгэхдээ узэл санаа-шинжлэх ухааны судалгаа-боловсруулах-шинжлэх ухааныг хэрэгсэн аж ахуй үйлдвэрийн бутээгдэхуүн үйлдвэрлэх-боловсон хучин бэлтгэх гэсэн гинжин холбооны амин чухал нэгдиийг хангах шинэ зарчимд тулгуурлах явдал чухлаар шаардагдав. Чухамдаа энэ замаар $п$ төр, нийгмийн зүгээс шинжлэх ухааны өмнө тавигдаж буй шаардлагыг ханганбиелуулэх байв. Бие даасан шинжлэх ухаан техникийнбодлого явуупах упс орондоо шинжлэх ухааныг удирдан зохион байгуулах, бүрдүупэхэд 1992 оны 1 дүгээр сарын 15-нд батпагдсан "БНКазУн шинжпэх ухаан болон төрийн шинжлэх ухаан техникийн тухай" БНКазУ-н хууль чухап уүрэг гүйцэтгэжээ. Мөн оны хоёрдугаар сард БНКазУ-н шинжлэх ухаан ба шинэ технологийн яам байгуулагджээ. Элгээр арга хэмжээ нь Казахстаны шинжлэх ухааны бие даасан бодлого болон шинжлэх ухааны удирдлагыг хэльбэржүулэн тогтох анхны чухал апхам байжээ. Эдгээр арга хэмжээнуүдийн үндсэн дээр нээлттэй эдийн засгийн нөхцөпд шинжлэх ухааны сапбарт удирдлагын хэлбэрийг эрж олох ажилд төрийн зугээс шургуу оржээ. Казахстанд энэ уед шинжлэх ухааны хөгжлийг чанарын шинэ шат, замд гаргахад наад зах нь маш чухал зарчмын гурван алхмыг хийх шаардиагатай байв.

Нэгдугээрт нь эрдэм шинжилгээ, судлагааны ажлыг төлөвлөх болон санхуужуулэхэд дан захиргааны аргаас татгалзан зорилтот хөтөлбөрийн аргад шилжих хэрэгтэй байв. Энэ нь судлагааны салбарт өрсөлдөөнийг бий болгож, улс орон эдийн засаг, нийгмийн хэрэгцээ шаардпагад нийцсэн узэл санаа, төспийг сонгон авч төрөөс дэмжлэг узуупэх бололцоог бий болгожээ. 1993 оны 1 дүгээр сарын 22-нд БНКазУ-н Сн3-ийн “БНКазУ-н шинжлэх ухаан болон шинжлэх ухаан болон техникийн хөтөлбөрийг төлөвлөх хэрэгжүулэхийг боловсронгуй болгох арга хэмжээний тухай" N• 61р тогтооп батпагджээ. Энд заагдсан хэрэгжүулэх арга хэмжээний дотор БНКазУ-н шинжлэх ухаан ба шинэ технологийн яамнаас санал болгосон шинжлэх ухаан ба шинжлэх ухаан-технологийн хөгжлийн тэргуипэх чиглэлээр судпагаа явуулах хөтөлбөр боловсруулах саналыг зөвшөөрч, хөтөлбөруүдийг хариуцах тэргүун байгууллагууд батлагдаж, ШУ, шинэ технологийн яамны дэргэд шинжлэх ухааны сан байгуупах болон санхуүжуупэх нөхцел, бодлогыг тодорхойлов. 
1995 оноос Казахстан улсын шинжлэх ухаан, технйкийн мэдээллийн хүрээлэнгээс норматив, арга зуйн суурь ундсийг боловсруулан шинжлэх ухаан, технологийн хөтөлбөрийг улсын нэгдсэн бүртгэлийн тогтолцоог бий болгож, шинжлэх ухааны удирдлагад бодит арга хэмжээ болгожээ. Түүнд тусупсад зохион байгуупагдах бахэрэгжуүпж буй шинжлэх ухаан, техникийн хөтөпбөрийн упсын цэсийн эрхпэх үүрэг, үйл ажиплагаа, техникийн хангамж, хөтөлбөрүудийн тухай мэдээплийн сан хөтлөх, батпагдсан хэлбэрээр тайлан буртгэх болон шинжлэх ухаан, техникийн хөтөлбөрийн даалгаврын биелэлтийн мониторингийн мэдээпэл-задлан-шинжилгээний хавсралт бэлтгэх явцад шинжлэх ухаан, техникийн хөтөлбөрийг хэрэгжүупэх ажлын цаг хугацаа зөрчигдөж байгаа эсэх, хөтөлбөрийг хэрэгжүүпэх явц тасалдан, саатах аюул байгаа эсэх болон хүлээгдэн буй үр дүн. гарсан /эс гарсан/ тухай зарлан шинжилгээний павлахыг бэлтгэн цаг тухайд дээд удирдпагад мэдээпэхэд оршино.

Хоёрдугаарт: постзөвлөптийн орон зайд Казахстанд анх удаа дэпхийн практикт өргөнөөр нэвтэрсэн шинжпэх ухааны бүх хөтөлбөр болон боловсруулалтанд бие даасан шинжлэх ухаан, техникийн шинжлэн магадлал хийх улсын шинжлэх ухаан-техникийн шинжлэн магадлах байгууллага /ГНТЭ/ байгуулагдав.

Гуравдугаарт: Казахстан нь зарчмийн болон хэлбэрийн хувьд цоо шинэ эрдэм шинжилгээ, судлагааны байгууллагууд болох үндэсний судлагааны төвуүдийг байгуулав. Энэ нь бодит чадамжтай хүчин чадал бүхий дан эрдэм шинжилгээний байгууплагуудыг нэгтгэн нэгэн удирдлагад төвлөруүпэхэд чухал түлхэц болсон байна. Өмнө нь бух холбоотын мэдэлд байсан цөмийн физик, биотехнологи, электроник ба хопбоо харилцаа, эрдсийн түухий эдийг боловсруугах туршиптийн талбай зэрэг эрдэм шинжипгээний байгууллагуудын суурин дээр үндэсний цөмийн төв, үндэсний биотехнопогийн төв, үндэсний эрдэс бодисийн туүхий эдийг нэн бүрэн боловсруулах төв, үндэсний радио электроник ба холбооны төв гэх мэт зохион байгуупагдав.

Казахстаны хувьд эдийн засгийн хүнд нөхцөлд асар богино хугацаанд шинжлэх ухаан, техникийн салбарт хэрэгжуүпсэн эдгээр зоримог алхам, шинэчпэп өөрчлөптууд нь ихээхэн зөв арга хэмжэээ байсныг амьдрал өдгөө нотпон харуулав. Одоо үндэсний цөм, биотехнологи эрдэс түухий эдийг боловсруулах гэх мэт төвууд амжилттай ажилпаж, бэхжин батжиж, шинжлэх ухааны төсөл, хөтөлбөрийн сонгон шалгаруулах бсйгуулпага болох Улсын шинжлэх ухаан-техникийг магадлан шинжлэх байгууплага (ГНТЭ) амжилттай 
ажиллаж байна. БНКазУ-ын Инженерийн Акалеми (2003 оноос Үндэсний Инженерийн Академи гэж нэрпэгдсэн) байгуулагдав.

II.Казахстаны шинжлэх ухааны хөгжил 1996-2000 онуудад

1990-ээд оны эхээр Казахстан нь эдийн засгийн хямралын хөгжлийн уе шатыг амжилттай даван туупж, Ерөнхнйлөгчийн стратегийн ёсоор улс орны эдийн засаг упс төр, нийгмийн салбарын тогтолцооны өөрчлөлт шинэчлэлтүудийг хэрэгжуүлснээр улс орон тогтвортой хөгжлийн замд орсон хэдий боловч Казахстанд шинжлэх ухааны салбар тун төвөгтэй хэвээр улдсэн байлаа. Эдийн засгийн хямралын упмаас тус оронд шинжлэх ухааныг упсаас бопон уйлдвэрийн хурээнээс санхуужуупэх хэмжээ багассан нь эрдэм шинжилгээ, туршилт-зохион бүтээх ажлын хэмжээ далайц эрс хумигдахал хүргэсэн байна. Судпагаа шинжилгээний бопон боловсруулсан зүйлийн ур дүнг нэхэж авахгүй орхих хүчин зуйлс үргэлжилсээр байжээ. Япангуяа сапбарын шинжлэх ухааны хувьд ихээхэн аюуп дагуулсан байна. Энэхуу аюулийг бодит амьдрап дээр пюстзөвпөптийн орон зайд цийлэнх орнуудын хуч чадамж бараг алдагдсан явдалтай холбон тайлбарлаж болох байв. Эдгээр үйл явц нь шинжлэх ухаан, технопогийн хучин чалалтай ОХУ-г мөн тойроогуй юм. Тийм нөхцөл Казахстанд бүрдэх нь магад байлаа.

Тус оронд шинжлэх ухааны боповсон хучний байдал эрс хурцдаж, эрдэм шинжипгээ болон шинжлэх ухаан-техникийн байгууллагад ажиллагсдын тоо тасралтгуй багассаар /1995 онд 25,37 мянган хүн байсан бол 2000 онд 14.76 мянган хүн/ байлаа 7 2000 оныг 1990 онтой харьцуупбал, эрдэм шинжилгээ-техникийн үйл ажиппагаа эрхэпдэг ажиптнуудын тоо гурав дахин, эрдэм шинжилгээ, шинжлэх ухаан техникийн сапбарын зардал 6,6 дахин хасагджээ $^{8}$. Энэ уед Казахстаны төрөөс шинжлэх ухааны чадамжийн ундсэн хэсэг бопох шинжлэх ухааны докторууд болон дэд эрдэмтдийг ихээхэн анхаарч шинжлэх ухааны салбартаа хадгалан упдэх арга хэмжээ авч байв. Эдгээр арга хэмжээний ачаар шинжлэх ухааны докторуудын багийн бурэлдэхуунийг бухэлдээ хэвээр хадгалан упдсэн төдийгүй тэдний тоог нэмэгдуулэх бололчоотой болжээ. Гэвч эрдэм шинжилгээнй̆ ажил эрхэлж байсан дэд эрдэмтдийн тоо хоёр дахин багассан байна. Шинжлэх ухааны салбарт хучээ сорих авьяаслаг запуучуудын урсгап татарч, тэд шинжлэх ухаанаас ипуу зах зээлийн бүтцэд ажилпахыг сонгож байв.

Дээд сургуупиуд, дээд боповсролын дараах сургаптуудад гажилт уусч, улс орны бодит хэрэгцээнд үндэслэгдээгүйгээр эдийн засаг, санхуу, хууль эрх зуй зэрэг мэргэжилтнуүдийг олноор бэлтгэж 
байв. Нарийн мэргэжлийн / дэд эрдэмтэд ба докторууд/ шинжлэх ухааны боловсон хучний бүтцэл өөрчлөлт гарч, нийгмийн болон техникийн шинжлэх ухааны боловсон хүчний тоон харьцаа жилээс жилд алдагдаж, нийгмийн шинжлэх ухааны эрдэмтдийн тоо эрс өсөөд байсан ба техникийнх багасаад байжээ. Ингээд 1992 онд нийгмийн болон техникийн салбарын доктор, дэд эрдэмтдийн хувь хэмжээ адил тэнцүу /40 ба 41,5\% харьцаатай/ - ээр барахгүй техникийнх бага зэрэг нэмэгдэж байсан бол 1996 онд нийгмийн шинжпэх ухааны сапбарын эрдэмтэд олонх болж 42,5\%-д хүрсэн бол техникийн сапбарынхан 36,7\%-тай байв9. Нийгмийн ухааны сапбарын эрдэмтдийн тоо цаашид нэмэгдсээр байсан бөгөөд 1999 онд 45\%, 2003 онд 50\%-нйг поктор, дэд эрдэмтэд эзпэх болсон байв. Энэ үед Казахстаны шинжлэх ухааны хөгжлийн хурдац нь упс орны нийгэм эдийН засгийн хөГжлийн явцаас ихээхэн хоцрогдсон нь нудэнд илт байсан бөгөөд эдийн засгийн хөгжлийн шинэ загварын эрчимтэй хурдыг даган гүйцэж чадахгүй байлаа. Ийм нөхцөлд, шинжлэх ухааны хөгжлийг улс орны хөгжилтэй уялдуулан амьдралд амьд барилпагатай болгон, бухэлдээ шинжлэх ухааныг дэмжин хөгжүулэхэд чиглэгдсэн шинэ загвар, арга зам, механизмийг эрж опох бүтээх эрэл хайгуул идэвхтэй хийх шаардлага гарчээ. Тийм механизмийн нэг нь аж үйлдвэр, эрчим хүч, барипга, тээвэр, харилцаа холбооны хөгжилийн асуудалаарх салбар дундын техникийн зөвлөл байгуулагдсан явдал юм. Шинжлэх ухааны амин чухал асуудпыг судлан боловсруупахад төсвийн санхуу монгөний ихээхэн хомсдоп бүхий хүнд жилуүдэд БНКазУ нь ТТУХН-ийн олонх орнуулаас ялгаран улс орныхоо сапбарын шинжлэх ухаан, төслийн байгууллагууд, мэргэжлийн шинжлэх ухаан инженернйн нэгтгэлуүдй̆г хэвээр хадгалан авч үлцэх бололцоо опсон нь тэдгээр салбарын эрдэм шинжилгээний байгууллагуудыг яаралтай төвпөрүупэх арга хэмжээг хэрэгжүулсэнтэй холбоотой юм.

БНКазУ-н Ерөнхийлөгчийн 1996 оны 3 сарын 11-ны өдрийн 슨 2895 тоот "БНКазУ-д шинжлэх ухааныг удирдах төрийн тогтолцоог боловсронгуй болгох арга хэмжээний тухай" зарлигаар Үндэсний Шинжлэх Ухааны Академи, Казахь:- Хөцөө Аж Ахуйн Академи болон 1992 онд байгуупагдсан шинжлэх ухаан, шинэ технологийн яамыг нэгтгэ, шинжлэх ухаан болон т ннийн хурээний төрийн удирдпага, төрийн шинжлэх ухаан, техникийн бодлогыг гардан хэрэгжүүпэгч нэгдмэл байгууплага болох БНКазУғ Шинжлэх Ухааны Яам - Шинжлэх Ухааны Академи байгуулагдан шинжлэх ухаан техникийн судлагааны суурь болон хавсарга 


\section{Казахстаны тусгаар тогтсоны дараах үенйн ШУ-ны хөгжнп}

судпагааны ажлыг удирдан санхуүжүупэх болжээ. Энэхүу байгууплага нь шинжлэх ухаан, техникийн удирдлагын хурээнд шинжлэх ухаан техникийн төрийн бодлогын зарчмийн асуудпууд, судлагааны чиглэл болон шинжлэх ухааны удирдпагын дүрэм журам, шинжлэх ухаан техникийн үйл ажиплагааны норматив-эрх зүйг боловсронгуй болгох асуудалд анхаарлаа төвлөруупсэн байна. Хөдөө аж ахуйн шинжлэх ухааны цаашдын хөгжилийг хангах, улс орноо хүнс болон хөдөө аж ахуйн туүхий эдээр хангах зорилтыг шийдвэрлэхэд хөдөө аж ахуйн шинжлэх ухааны хувь нэмрийг нэмэгдуүпэх, хөдөө аж ахуй аж үйлдвэрийн цогчолборын салбарийн шинжлэх ухаан-техникийн хүчин чадлыг төвпөруупэх зорилгоор Казахстаны Шинжлэх Ухааны Яам-ШУА-н хөдөө аж ахуйн чиглэлийн эрдэм шинжилгээ судпагааны байгууплагууд, туршилтын аж ахуй , туршипт үйлдвэрийн газруудын суурин дээр БНКазУ-н Үндэсний Хөдөө Аж Ахуйн Академийн төвийг 1996 оны 5-р сард байгуупав. Энэ үед тус упсын эдийн засгийн байдал тогтворжсон нь эрдэм шинжилгээ, туршилт, зохион бүтээх байгууллагуудыг дэс дараагаар ажлаар ханган, улсын төсвөөс санхүүжүупэх болопцоог нэмэгдүүпэв.

ШУА-д шинжлэх ухааныг санхуужуулэхээр төсвөос төлөвлөсөн мөнгий ур ашигтай зарцуулах ихээхэн хариуцлага ноогдож байсан нь энэхуу зардал мөнгө нь шинжлэх ухаан-техникийн уйл ажиллагаанд бух эх үүсвэрээс гаргаж байсан зардлын тэн хагастай тэнцэж байсан явдал байлаа. БНКазУ-д шинжлэх ухааны сапбарыг цаашид өөрчлөн шинэчлэх асуудал нь БНКазУ-н засгийн газрын 1998 оны12 сарын N• 1335-аaр "Упсын төсвийн хөрөнгөөр санхүужиж буй байгууплага захиргааны асуудлууд" гэсэн тогтоолд тусгалаа олжээ. Тус тогтоолын дагуу эрдэм шинжипгээний бух байгууллагуудыг төрийн шинжлэх ухааны байгууппага болгон өөрчпөн байгуупсан байна. 1999 онд БНКазУ-н засгийн газрын дэргэд шинжлэх ухааны асуудпаар заавар зөвөлгөө өгөх зөвлюх байгуулпага- Шинжлэх ухаан- техникийн дээд комисс байгуупагдав. Тэр нь суурь болон хавсарга шинжлэх ухааны хөгжлийн талаар төрөөс анхаарал хандуупах чиглэлуүдийг тодорхойлох, түунийг хэрэгжүүлэх арга замын талаар зөвлөмж бэлтгэх болон шинжлэх ухаан, шинжлэх ухаан- техник, инновацын төрийн бодлогыг упам боловсронгуй болгох зэрэг ажлыг хариуцан гүйцэтгэдэг байна. Казахстаны эдийн засгийн хөгжлийн инновацын шаардлага нөөц бололцооны нөхцөлд нийцсэн шинжлэх ухаан, техникийн хүрээний тогтвортой хөгжлийг хангах, шинжлэх ухаан, техникийн чадамжийг бүрдүулэх зорилгоор 2000 оны 6-р сард БНКазУ-н засгийн 
газрын `1059 тоот "БНКазУ-н шинжлэх ухаан, шинжлэх ухаантехникийн бодлогын үзэл баримтпалын тухай" тогтоол батпагджээ. Энэхуү баримт бичигт төрийн шинжлэх ухаан, шинжлэх ухаанытехникийн бодлогын урьтач үндсүуд, зарчим, зорилт, зорилгуудыг тодорхойлсон байна. Шинжлэх ухаан, шинжлэх ухаан- техникийн төрийн бодлогыг хэрэгжуүпэхэд зорилтот хөтөлбөрийн арга зүйн зарчмийг баталгаажуулсан нь шинжлэх ухааны бүхий $\Lambda$ үйл явцыг баяжуупсан бөгөөд ирээдуйд шинжлэх ухааны, шинжлэх ухаантехнологийн бодлогыг хэрэгжүулэх үндсийг улам баталгаатай үндэспэптэй болгожээ.

III.Казахстаны шинжлэх ухааны хөгжил- 2000-2006 онуудад

Казахстан эдийн засгийн хямралыг даван туупсны дараах бодит амьцралд зохицсон БНКазУ-н “Шинжлэх ухааны тухай" хууль 2000 оны 6 сард батпагдав. Шинжлэх ухааны байгууплагуудыг шинэчлэн байгуулсны дараа төрийн шинжлэх ухааны, шинжлэх ухаан-технологийн бодлогыг гуйцэтгэгч нь БНКазУ-н Боловсрол ба Шинжлэх Ухааны Яам болов. Казахстан нь шинжлэх ухааны удирдлагын шинэ загвараа боловсруупан нэвтруүпэхэд Финланд. АНУ, Өмнөд Солонгос зэрэг дэпхийн хамгийн өрсөпдөх чалвар бүхий орнуудын туршлагыг анхааран үзсэн байлаа. Энэхуу шинэ загварын гол нь санхуужуулэлтийн зарчмийг өөрчлөх явдал байсан бөгөөд шинжлэх ухааны байгууплагыг эрдэм шинжилгээ, судлагааны төсөл санхуүжүулэх зарчмаар удирдахад оршино. Шинэ зарчимд шилжсэнээр төсвийн хэсгийг БШЯ ба салбарын яамдад дахин хувиарлахал хүрсэн байна. Энэхуу журам нь улс орны бодит эдийн засгийн салбарын хэрэгцээг хангахад хамгийн түруунд санхүу мөнгө, боловсон хүчин болон шинжлэх ухаан-техникийн хүчин чадлыг шинжлэх ухааны хамгийн тэргүупэх сапбарт төвлөруүлэх болол:іоо опгосноороо давуу талтай юм. Энэхуу хуулийн заалтын дагуу улсын захиалгаар сонгон шалгаруупалтын үндсэн дээр упсын шинжлэх ухаан-техникийн хөтөлбөрийг хэрэгжүулэх эрдэм шинжилгээ, туршилт-зохион бүтээх ажилд зарцуулах төсөв мөнгөний санхуужилтийг зорилттой ашиглах явдлыг бэхжүулэв. Энэ уед шинжлэх ухааны салбарыг өөрчлөн байгулпах аж жг улам боловсронгуй болгох зорилгоор шинжлэх ухааны байгууплагуудад мэргэжлийн үнэлгээ дүгнэлт өгсөн байна.

БНКазУ-н засгийн газрийн 2002 оны 6 сарын 28-ны өдрийн •• 704 тогтоолд БШЯ-ны харьяанд байсан 70 гаруй упсын үйлдвэрийн газрыг Хөдөө Аж Ахуйн Яамны мэдэлд шипжүүлсэн байна. Дараа нь эдгээрийг нэгдмэл инновашын бүтэц болох "КазАгро Инновация"- 
д төвлөруүпсэн бол сүүпд "КазАгро" үндэсний холдингийн мэдэлд өгчээ. БНКазУ-н Ерөнхийлөгчийн зарлигаар 2003 оны 3-р сард ШУА-ийн удирдлагад байсан эрдэм шинжилгээний хүрээлэнгүуд салбарын яамдын эрх мэдэпд шилжсэн учир үндэсний ШУА нь улсын нийгмийн нэгдлийн статустай болж, академийн шннжпэх ухааны мэргэжилтний тоо мэдэгдэхүйц багассан бол салбарын шинжлэх ухааны боловсон хучний өсөпт /2007 он хуртэл/ нэмэгдэв. Энэ өөрчлөлт нь шинжлэх ухааны төвуудэд тавих хяналтыг хүчтэй болгож, эрдэм шинжилгээ, туршилт-зохион бутээх болон хавсарга судлагааг зааглан тогтоов. Эрдэм шинжилгээ, туршилт зохион бүтээх ажлыг шинэ зарчмаар зохион байгуупсан нь төрөл бүрийн салбарын шинжлэх ухаан техникийн стратеги нэгдмэл цогцолбор бопох интеграцийн урьтач нөхциийг бүрдуулэв.

Казахстанд орчин үеийн нийгмийн шинжлэх ухааны уүргийг ойлгоход БНКазУ-н Еронхийлөгчийн дэвшүүпсэн үндэсний инновацийн тогтолцоог байгуулах тухай узэл санаа нь зарчмийн шинэ зүйл болов. 2002 онд БНКазУ-ын "Инновацийн үйл ажиллагааны тухай хууль" батлагдан инновацийн хүрээний уйл ажилпагааны харипцааг зохицуупах болон суурь зарчмуудыг төрийн инновацийн бодлогыг хэрэгжүупэх чиглэл, хэлбэр, арга замыг тодорхсйлжээ. 2015 он хүртэлх аж үйлдвэр инновацийн хөгжлийн стратегийг 2003 онд боловсруупсан байна. Энэ нь тус орны эдийн засагт бүрэлдэн бий болсон нохцөл байдалтай уялдан гарч иржээ. Тухайн цаг үед аж үйлдвэрийн хөгжлийн хурдац буурч, 2003 онд дотоодын нийт бүтээгдэхүүний үйлдвэрпэлийн хэмжээ барагцаалбал 4,5 трилпион тг байсан боп энэ нь үндсэндээ байгалийн хий, газрын тосны цогцолбороор хангагдаж байв. Казахстан нь дэлхийн зах зээлд нуүрс ус төрөгч, газрын тосны хувирамтгай учир байдал, байгалийн баялагийн нөөц хязгаартай, дахин сэргээх бололцоогүй зэргийг харгалзан үзээд түухий эдийн эдийн засгаас хөГжлийн өндөр түвшний бүтээгдэхуүний экспортод суурипсан сервис-технологийн эдийн засаг руу аажмаар шилжих, урт хугашааны загварыг хамгийн богино хугацаанд боловсруупах шаардлагатай болсон юм. Энэхуу алхам нь здийн засаг дахь шинжлэх ухааны хэрэгцээ шаардиагыг сэргээн, хучтэй болгох чухал сувгуудын нэг юм. Энэ нь эрдэмтдийг улс орны хөгжилд бодит хувь нэмэр оруупах болон тэдний нийгэм, эдийн зассаг, ёс зүйн статусыг шинэ өндөр түвшинд гаргах билээ. Өмне тавьсан эдгээр зорилтуудыг биелуулэхэд олон арга хэмжээ авч, хөгжлийн суурь бүтцүуд зохион байгуупагдсаны дотор Казахстаны Хөгжлийн Банк, Хөрөнгө Оруупаптын Сан, Үндэсний Инновацийн 
Сан, Инжиринг ба трансферийн төв гэх мэт байна. Сапбар болон салбар хоорондын шинжтэй хөтөлбөруүд батлагдсаны дотор үндэсний инновацийн тогтолцоог бүрдуүпэн хөгжүүпэх, барилІгын үйлдвэрлэл, эрчим хүчний хангамжийн гэх мэт хөтөлбөруүд оржээ. Энэ уед 20 илуу шинэ хууль батлагдсаны дотор "Техникийн зохицуупалт", "Хөрөнгө оруулалтын сангийн тухай", гэх мэт байсан хийгээд тээвэр, эрчим хүчний дэд бутцийн хөтөлбөручдийн ажил эхлэв. 2006 оноос эхлэн аж үйпдвэр-инновацийн хөгжил ба 20052015 онд үндэсний инновацийн тогтолцоог бүрдүупэн хөгжүүпэх хөтөлбөрийн хүрээнд 520 хөрөнгө оруупалтын төсөл хэрэгжиж байна. Холбогдох байгууплагуудын ивээл дор 2,2 тәрбум долпарын өртөг бүхий 90 төспийг хэрэгжүупэх ажил эхэлжээ. Түухий элийн биш эдийн засгийн салбарыг хөгжуүпэх зорилгоор эхэлсэн чухал төспүуд амжилтттай хэрэгжиж байгаагийн дотор Жанажолийн байгалийн хий боловсруупах гуравдахь үйпдвэр, уулын баяжуулах үйлдвэрүүд, Актөбегийн зэс хайлуупах үйлдвэр, Павлодарийн хөнгөн цагааны үйлддвэий̆ барилга гэх мэт аж үйпдвэрийн чигпэлийн бусал олон тоспуүд хэрэгжив.

IV.Казахстаны шинжлэх ухааны хөгжил 2006-2013 онуудад

БНКазУ-н засгийн газрын 2006 оны 7-р сарын N•700 тогтоопд БНКазУ-н Боловсрол ба ШУ-ны Яаманд Шинжлэх Ухааны Хороо байгуулагдсан бөгөөд түүний гол үурэг нь шинжлэх ухааны хүрээнд төрийн нэгдмэл бодпогыг хэрэгжүүпэх явдал юм. БНКазУд 2007-2012 онд ШУ-г хөгжуүпэх төрийн хөтөлбер боловсрогдон түуний хүрээнд засгийн газрийн дэргэдэх зөвлөх байгууппага болох Шинжлэх Ухааны-Техникийн Дээд Комиссын статус дээшлэв. УГ комисс нь төрөөс суурь болон хавсарга шинжлэх ухааныг хөгжуүпэх уртач чиглэлийг тодорхойлон, хэтийн төлөөлпийг боловсруулах уүрэгтэй бөгөөд ерөнхий сайд толгойлдог байна. Мөн ЏУ-ны магадлан шинжлэх ажиллагааг боловсронгуй болгон дээрх комиссын дэргэд олон упсын магадлан шинжлэх зөвлөл ажипладаг ба түүний бүрэлдэхуүнд Казахстаны өөрийн болон гадаадын нэрт эрдэмтэд ордог юм. Шинжлэх ухаан техникийн дээд комисс сайшаасны үндсэн дээр эрдэм шинжилгээ судлагааны шинэ төспийг санхуүжүүпсэн ажлыг шийдвэрлэдэг байна. 2006 онд байгуупагдсан Шинжлэх Ухааны Сан нь тус улсын 2006-2012 онд хэрэгжуүпсэн шинжлэх ухааны хөтөлбөрийг гүйцэтгэхэд чухал байр суурийг эзлэв. УГ Сан нь 2008 оноос Үндэсний шинжлэх ухаан техникийн холдинг "Парасат"-н бүтцэд орсон бөгөөд шинжлэх ухааны тэргүупэх, санаачилсан, аз туршсан болон туршилт-зохион 
бүтээх ажлын хөгжилд хучээ дайчлагсдад дэмжлэг үзуүпж байна. Шинжлэх ухааны санд нийт 515 захиалга санхүужүүпэх санал ирсний дотор хавсарга судпагааны шинж чанартай, туршилт зохион бүтээх, санаачилсан болон аз туршсан хавсарга судлагаа болон инновацийн шинж чанартай төспучд юм. Эдгээр захиалгаас ШУны сан нь эхний ээлжинд 33 төспийг шийдвэрлэн санхуужуүпсэн байна.

Грант опгох замаар санхуужүүпсэн 22 төспийг гүйцэтгэсэн хийгээд эдгээрээс 2008 онд 3, 2010 онд 15, 2011 онд 4 төспийг тус тус хэрэгжуүпэн дуусчээ. Грантаар санхүужүупсэн эдгээр 22 төспөөс 7 нь патент, 2 нь зохиогчийн гэрчилгээ авч, 13-д үндэсний оюуны өмчийн хүрээпэн /РТКП/ захиалга өгчээ. Эдгээр бүх оюуны бүтээлийн эрх эзэмшигч нь гүйцэтгэгчийн хамтаар ШУ-ны сан адил тэгш эрх эдэлдэг. 2008 онд ШУ-ны сан нь 197/нийт мөнгөн дүнгээр 18378,9 сая тг/ захиапга хупээн авсан бөгөөд тэдгээрээс нийт мөнгөн дүнгээр 1956,4 сая тг-ийн 129 грантыг санхуүжүүпжээ. Тус сан нь нанотехнопоги ба шинэ материалын 9 төспийг 263,0 сая тг-ээр санхуүжүүпсэн бол 2240,4 сая тг-ний өртөг бүхий биотехнологийн 33 төсөл, ус нүүрстөрөгч, уулын төмөрлөгийн салбарын болон тэдгээрт холбоотой сервисийн сапбарын 73 төслийг 7926,8 сая тг-ээр санхуужучпсэн байна. Цөмийн технологи болон сэргээгдэх эрчим хучний 16 төспийг 830,0 сая тг-ээр, мэдээпэл бопон сансрын технологийн 21 төспийг 2116,9 сая тГээр санхуүжуүпжээ. Шинжлэх ухааны тэргуүлэх чиглэл, ихээхэн үр ашиг бүхий сонгон шапгаруупалтаар сонгосон, практик ач холбогдол бүхий хавсарга, эрдэм шинжипгээ -судлагааны туршилт зохион бүтээх анхны төслийг нэн түруунд санхүүжуүпж байгаа нь бодит ахиц гарах үндсийг бий болгож байна. Казахстаны хөгжилд аж үйлдвэр инновацийг хурдасгахаар заасан төрийн тэргуүн Н.А.Назарбаевийн бодпогыг хэрэгжүулэх уе шатанд шинжлэх ухааны сан байгуупагдсан нь нааштай чухал алхам болсон бөгөөд шинжлэх ухаан-техникийн хөгжилд таатай нөхџөл бүрдуупэн, НЦНТИ-тэй хамтран эрдэм шинжипгээ, инноваци болон хөрөнго оруупалтын төспийн хамт гүйцэтгэхэд ач хопбогдоптой билээ. БНКазУ-н засгийн газрын шийдвэрээр улс орныхоо шинжлэх ухааны чадамжинд иж бүрэн аудитын шалгалтыг 2006 онд хийж, цавуу болон сул талаа ипруулэн тодруулав. Энд АНУ-н Үндэсний Академийн тэргуүпэх эрдэмтдийг татан оропцуупсан байна. Аудитын үр дүнд тус улсын шинжлэх ухааны хөгжлийн түвшин нь дэлхийн түвшний амжилтанд хүрэхэд шаардагдах үндэс суурь нэгэнт бүрдсэн 
байна.гэж дүгнээд Казахстаны шинжлэх ухааны хөгжлийн тэргүүпэх чиглэлуүдийг тодорхойлж, анхаарах асуудиуудын талаар тодорхой зөвлөгөө өгсөн ажээ. ШУ техникийн аээд комисс нь 2007-2009 оны хооронд судлагаа явуулах тэргуупэх таван чиглэлийг баталсан байна. Эдгээр нь

1. Нанотехнопоги, шинэ механизмууд

2. Биотехнологи

3. Нуүрс устөрөгч, уупын төмөрпөгийн сапбарын технологи, эдгээртэй холбоотой сервисын салбар

4. Цөмийн ${ }^{11}$ болон сэргээгаэх эрчим хучний технологи

5. Мэдээлэл ба сансарын технологи ${ }^{12}$ болно.

Эдгээр салбар тус бүрээрнь тусгайшинжлэхухаан-технологийн хөтөлбөруүд батлагдан, ШУТДК-ээр хянагдан, амьдралд амжилттай хэрэгжих шатанд явж байгаа юм. Гэвч шинжлэх ухааны ололтуудыг практикт хэрэгжүүлэх талбарт хүнд байдал үргэлжлэн, шинжлэх ухаан ур дүнг бодит шинэ бүтээгдэхуүн болон технологи болгон хувиргах чадвар бүтээмжтэй технологийн дэд бүтэц хангалтгүй байв. Бизнесийн хүрээнийхэнд шинжлэх ухаанд хөрөнге оруулах тогтолцооны хөгжлийг дэмжих сонирхол төрөхгүй байв. Энэ үед Казахстаны засгийн газар шинжлэх ухааны хүрээн дэх өөрийнхөө оролцоог эрс хумисан бөгөөд зөвхөн аж үйлдвэр хувийн пүүсүүдийн хүч үл хүрэх чигпэпийн судпагааг $\pi$ өөртөө упдээсэн юм. Тус улсын төрийн шинжлэх ухаан-техникийн бодпогын гол цөм нь дэлхийн зах зээлд Казахстаны аж үйлдвэрийн өрсөлдөх чадлыг дээшлүүлэхийн тупд үйлдвэрлэпд шинжлэх ухаан, техникийн ололтыг нэвтруүлсэн үйл явцыг хурдасгахад оршино. Нөгөө талаар шинжлэх ухааны багтаамжтай стратегийн аз туршсан технологийг улсын хотөлбөрийн хүрээнд хэрэгжүүпэх хийгээд нөгөө талаар өрсөлдөөн нь шинжлэх ухаан-техникийндэвшлийгудирдан явуупахбодит механизмболоогуй гэж үздэг хумүүс байна. Ийм нөхцөлд шинжлэх ухаан, техникийн холдингууд байгуулах санал урган гарсан бөгөөд тэр нь хэлбэрийн хувьд төрийн / дүрмийн хөрөнгө оруупалт нь 100\% төрийнх бөгөөд бодит хэмжээнээс хувь нийлүүпэгийн эрх хамаатай/ агуулгын хувьд зах зээлийн. 2007 онд БНКазУ-н засгийн газар нь үндэсний ШУТн холдинг "Самгау" -г /100\% улсын хөрөнгөөр/ хувь нийлүүпсэн нийгэмлэг байгуулсан байна. Үүний дагуу аж ахуй үйл ажилпагаа явуупах эрх бүхий улсын үйлдвэрийн газруудыг дүрмийн хөрөнгө оруупалтал хувь нийлуүпсэн байгууплага болгон өөрчпөн байгуулав. 2008 онд "Самгау"-г өөрчлөн үндэсний мэдээлпийн "АрнаМедиа", Үндэсний Шинжлэх Ухаан, Техникийн холдинг "Парасат" болон 
үндэсний мэдээлэл холбооны холдинг "Зерде" байгуупагдав. Шинэ технологийн паркууд-Алматад инновацийн технопогийн, Оралд машин үйлдвэрлэлийн, Карагандад төмюрлюгийн, Өскеменд технопарк, цөмийн технологийн парк-"Токамак" Курчатов хотод, сансрын мониторингийн технопарк Приозерск хотод байрлан тус тус нээгдэв.

Боловсроп, шинжлэх ухаан, инновацийн уйл явдлыг интеграцчилах зорилгоор хамгийн орчин үеийн төхөөрөмжөөр тоноглогдсон нээлттэй хэлбэрийн 20 шинжлэх ухааны паборатори байгуупагдсан бөгөөд тэдгээрт тус упсын иргэн хэн ч судиагааны ажил явууупж болох ажээ.

Боловсроп ба шинжлэх ухааны интеграцчиллийн тод жишээ нь Назарбаев их сургуупь бөгөөд оюунлаг ундэстэн бурдучлэх гурван гол төлвийг нэгтгэсэн ажээ. Тус сургуулийн дэргэд дэлхийн түвшний 3 төв байгуулагдсан богөөд тэдгээр нь судлагааны ажил явуулахын хамтаар сургалтыг шинжлэх ухаантай хоспуулах, шинжлэх ухааны бодит үр дүнг үйлдвэр болгон худалдааны инновацид нэвтрүупэхэд чиглэгджээ. Тус их сургууль нь дэлхийн практикт ховор тохиолддог жишээний нэг бөгөөд боловсон хүчин, аж ахуй, санхуугийн нөөц, оюуны чадамжийг цоо шинээр бурдүулжээ. Их дээд сургуулиудад өөрийн дэргэд эрдэм шинжилгээний хүрээлэн, төвуүдийг байгуулах ажил өрнөв. Тухайлбал Казах-Британи их сургуулийн дэргэд 9 эрдэм шинжилгээний паборатори үйл ажиллагаа явуупж байна. Астана хотод дэлхийн стандартыг хангасан үндэсний биотехнологийн төв байгуулагдлаа. 2010-2014 онд үйлдвэр- ннновацийн үйл явцын зорилт бүхий таван жилийн хөтөлбөрийг хэрэгжуүпж байна. Энэхуу хөтөлбөр нь шинэ нөхцөлд, эдийн засагт диверсифиикаци хийх, технопогийг чанарын ондөр түвшинд гарган, шинжлэх ухаан шингээсэн шинэхэн бүтээгдэхүун үйлдвэрлэхэд чиглэгдэж байна. Үйлдвэр-инновацийг хэрэгжүупэх нь шинжлэх ухааны салбарын амин чухал зорилт юм. 2010 оны 11-р сарын 30-ны БНКазУ-н засгийн газрын тогтоолоор 2010-2014 онуудад инноваци болон технологид шинэчлэл хийх зорилгоор эрдэм шинжилгээ, туршиптзохион бугээн ажилд дотоодын нийт бутээгдэхууний нэг хувьтай тэнцэх зардал гаргах болжээ.

2011 оны 2 сард "Шинжпэх ухааны тухай" хуупь батпагдсан бөгөөл шинжлэх ухааныг удирдах ооо шинэ загварыг хэрэгжуулэхэд чиглэгдсэн юм. Өнөөгийн Казахстанд шинжлэх ухааныг удирдах шинэ тогтолцоог бүрдуупсэн, уг тогтолюонд оролцогч бүрийн үүргийг дээшлуүиэв. Энэ нь судлагааны ажлыг санхуужүүпэх, эрдэм 
шинжилгээний ажлын сэдвийг сонгох, судлагааны ажлын үр дүнг хэрэгжүүпэхэд эрдэмтдийн оропцоог дээшлуүлэх, упсын магадлан шинжлэх ажилпагааг боловсронгуй болгох, судпагааны ажлыг санхуүжуүпэх бопон үр дүнг үйлдвэрт нэвтруүлэх, хувийн хэвшлийг өргөнөөр татан оролцуулахал чиглэгджээ.

Энэхуч хуупинд шинжлэх ухааны хүрээнд өрсөпдөөн бий болох нөхцөл бүрдэн шинжлэх ухааны тогтолцоонд тэнцвэрийг хангаж, шинжлэх ухааны мэдлэг уе улиран хадгапагдах нөхциийг бүрдүүлсэн нь улс орны нийгэм, эдийн засгийн хөгжилд чухлаар нөлөөлж байна. Шинжлэх ухаан болон шинжлэх ухаан-техникийн үйл ажиллагааны удирдлага нь стратегийн магадлан шинжлэх болон захиргааны чургуүдэд нь БНКазУ-н ШУТДК, Үндэсний эрдмийн зөвлөлуүд улсын шинжлэх ухаан-техникийн магадлан шинжлэх үндэсний төв болон салбарын эрх бүхий байгуулпагуудад хувиарлагдан хэрэгжиж байна. Шинжлэх ухаан, шинжлэх ухаантехникийн болон инновацийн үйл ажиллагааны онцлог, төсвийн хөрөнгийг илүү ур дүнтэй ашиглах, шинжлэх ухааны салбарын санхуүжилтыг үндсэн зорилтот хөтөлбөрийн, грантын хэлбэрээр хийж байна. Тэрчлэн хуупинд эрдэм шинжилгээний ажилтныг дахин шалгаруулах, боловсон хүчин бэлтгэх болон эрдэм шинжилгээний ажилтан, түуний дотор запуу эрдэмтдийг урамшуулах хэм хэмжээг заажээ. БНКазУ-д "Шинжлэх ухааны тухай" хууль хэрэгжиж байна. Шинжлэх ухааны сапбарыг санхүужуүпэх засгийн газрын шинэ журам батлагдан, суурь, зорилтот хөтөлбөр, грантын хэлбэрээр санхүүжүүпэх байгууппагын нэрсийн жагсаалт гарч үндсэн суурь санхуүжуүпэлтэнд 161 шинжлэх ухааны байгууплага хамрагдах болов.

ШУТДК нь 2011-2013 онуудад судлагаа хийн шинжлэх ухааны тэргуулэх чиглэлуудийг тодорхойлов. Тэдгээр бух тэргүүпэх чиглэлийн судлагааны эшсийн зорилго нь Казахстаны шинжлэх ухааныг дэлхийн түвшинд хүргэх, үр дүнг нь улс орны нийгэм, эдийн засгийн инновацын хэрэгцээ шаардлагыг хангахад дээд зэргээр дайчпах явдал юм. Эдгээр сапбар нь эрчим хүч бопон түҮхий эд болон бутээгдэхуүнийг гүн боловсруулах мэдээлэл болон телекоммуникацийн технологи, амьдралын тухай шинжлэх ухаан, улс орны оюунлаг чадамжийг дээшлуүлэх зэрэг юм. Эхний гурав нь эдййн засаг, инновацийн хэтийн төлөвлөлт хамааралтай бол дараагийнх нь нийгмийн чиглэлтэй, тав дахь нь чанарын шинэ чиглэл бөгөөд улс үндэстнийхээ оюунлаг чадамжийг дээшлуүпэхэд оршино. Хуулинд байгаа суурь шинжлэх ухааны хамтаар нийгмийн шинжлэх 
ухааны судлагаа хийхээр заасан бөгөөд энэ өргөн агуупгаараа Казахстанд суурь шинжлэх ухааныг хөгжүупэхэд нөпөөлөх юм. Хуупийг хэрэгжуупэх хүрээнд Казахстаны болон гадаадын эрдэмтдээс бутсэн үндэсний эрдмийн зөвлөпууд байгуупагдпаа.

\section{Бугд Найрамдах Казахстаны Упсын шинжлэх ухааны сапбарын хуупь, эрхзүйн өөрчлөлт, шинэчпэл}

Бүгд Найрамдах Казахстан Упсын шинжлэх ухааны сапбарын хууль тогтоох болон нормативын баримт бичгуудийн шинж чанараас улбаалан Казахстанд шинжлэх ухаан бопон шинжлэх ухаан-техникийн үйл ажиплагааны хууль эрх зуйн үндсийг бурдуулэх талаар их ажил хийгдэв. Энэ талаар эрх бухий байгууплагуудын түвшинд хууль болон нормативын баримт бичгүудийг бэлтгэх, улсын иөтөлбөрийг боловсруулах, батлагдсан хуупиудыг эрдэм шинжилгээний хамт опноор өргөнөөр шуун хэлэцэх, тэдгээрийн тусгагдсан заалтыг хэрэгжүупэхэд онцгой анхааран ажиллажээ.

Бугд Найрамдах Казахстан Упсын шинжлэх ухааны түухэнхууль, эрхзуй хөгжлийг ундсэндээ гурван уе шатанд хуваан узэж бопох ажээ.

Нэгдугээр уе шат: 1991-1995 оноос хамаарах бөгөөд энэ үед Казахстаны шинжлэх ухаан техникийн бодлого болон шинжпэх ухааны удирдах тогтопцоо бурдэж эхэлжээ.

Хоёрдигаaр vе шат: 1996-2000 онуудад шинжлэх ухааны байгууплагуудыг өргөн хэмжээгээр өөрчилж шинэчилсэн уе юм.

Гupaвдигаaр vе шат: 2001 оноос одоо хуртэлх уед хопбогдох ба шинжлэх ухааны удирдах болон шинжлэх ухаан техникийн салбарыг норматив-эрхзуйн үндсийг боловсронгуй болгосон явдал юм.

1991 онд Казахстан тусгаар тогтносны дараа шинжлэх ухаан, ;шинжлэх ухаан-техникийн хөгжил дэвшлийн талаар шинэ үзэл санаа бүрэлдэн бий болов. Бие даасан шинжлэх ухаан техникийн бодпого ба улс орондоо шинжлэх ухааныг удирдах тогтолцоог бурдуулэх асуудлыг 1992 оны нэгдугээр сард батпагдсан "Бүгд Найрамдах Казахстан Упсын шинжлэх ухаан, төрийн шинжлэх ухаан-техник болпогын тухай" хуупийг үндэс бопгов. Шинжлэх ухаан, шинэ технологийн яам нь 1993 оны гуравдугаар сарын 19-нд байгуупагдав. Хэд хэдэн удаагийн зохион байгуулалтын өөрчлөлт шинэчлэлт явагдсаны эцэст төрийн шинжлэх ухаан, шинжлэх ухаан-техникийн бодлогыг гардан хэрэгжүупэгч байгууплага нь Бугд Найрамдах Казахстан Упсын 


\section{М.Хурметхан}

Боловсроп ба Шинжлэх ухааны яам болов. 1992 оноос эхлэн Казахстан Упсын Ерөнхийлөгч болон засгийн газраас шинжлэх ухаан, шинжлэх ухаан техникийн холбогдолтой 100 орчим баримт бичиг батлан гаргаснаар шинжлэх ухааны салбарын үйл ажилпагаа хангалттай хэмжээний эрх зуй болон норматив баримт бичгээр хангагджээ.

Засгийн газрын тогтоопуудаар бүх шинжлэх ухааны байгууплагууд упсын шинжлэх ухаан-үйлдвэрийн газар болж, шинжлэх ухааны салбарт өрсөлдөөн бий болгох, судлагааны ажлыг зорилтот хөтөлбөрийн аргазуйгээр гүйцэтгэх, шижлэх ухааны хараат бус улсын шинжлэх ухааны магадлал явуулах зэрэг ажлууд хийгдэв. Мөн “Шинжлэх ухааны тухай" (2001), "Зохиогчийн эрх ба хязгаарлагдмал эрхийн тухай" (1990) "БНКазУ-ын патентийн хууль "(Шинэчилсэн эх-1999)" зэрэг нь шинжлэх ухаан, шинжлэх ухаан-техникийн үйл ажиллагааг явуулах эрхзуйн орчинг сайжруупахал хувь нэмэр оруупав. Шинжлэх ухааны хуупиар төрөөс шинжлэх ухаан, шинжлэх ухаан- техникийн сапбарын инновацийн үйл ажиллагааг хэрэгжүулэх бүх байгууплагуудад эрх тэгш бололшоо бүрдүупэх замаар дэмжихийг заажээ. Энд мөн технологийн хөгжил, инновацийн хөгжлийн урт хугацааны хөтөлбөр боловсруулах, инновацийн хөтөлбөрийг санхуужүулэх, инновацийндэд бүтцийнхегжилдтуспах, инновацийнменежерүүдийг сургані бэлтгэх г.м тусгагдсан байна. Эдгээрт холбогдсон хөрөнгө оруулалтыг татах зорилготой пицензийн тухай, шинжлэх ухаан, технологийн сапбарын зарим хөнгөлөлт узуупэх тухай татварын хууль, инновацийн хууль батпагдав. Шинжлэх ухааны салбарын хууль, эрхзүйн хувьд шинэчпэхэд хуулиуд (шалгалт, татварын гааль, хөрөнгө оруупалт, хувьчпах, упсын үйлдвэрийн газрын тухай г.м) хязгаарпагдмал шинжтэй байна.

Казахстанд шинжлэх ухаан техникийн бодлогын хууль эрх зүйн бодпогыг упам боловсронгуй болгох бодит шаардиага байсан бөгөөд энэхуу асуудлыг шийдвэрлэхэд 2011 онд батпагдсан Бугд Найрамдах Казахстан Упсын “Шинжлэх ухааны тухай хууль амин чухал байсан байна. Ийнхуу тус улсад шинжлэх ухааныг хөгжүупэхийн төлөө шаардлагатай зохион байгуулалт болон хуупь эрх зүйн үндэс бүрдсэн бөгөөд таатай инновацийн нөхшөп бүрдэж, эдийн засгийн хөгжилд хувь нэмэр оруупж чадахаар болсон юм. Шинжлэх ухааны тухай хуулиар шинжлэх ухаан, шинжлэх ухаантехникийн сапбарын нийгмийн харипцааг зохицуулан Казахстаны үндэсний Шинжлэх ухааны тогтолцооны ажиллагаа болон түүнийг 
хөгжүупэх үндсэн зарчим болон механизуудыг тодорхойлсон байна. Хуупийн "Ерөнхий журам дүрэм" гэсэн нэгдүгээр бүпэгтээ уг хуулинд ашиглагдах үндсэн 29 ойлголтыг тайлбарпасан байна. Мөн Казахстан улсын шинжлэх ухааны талаар өгүүпжээ.

Хуупийн хоёрдугаар бүпэг нь төрийн байгууппагуудын шинжлэх ухаан ба шинжлэх ухаан-техникийн салбар дахь эрхийн асуудлыг тусгажээ.

Гуравдугаар бупэгтээ шинжлэх ухаан ба шинжлэх ухаантехникийн үйл ажилпагаанд субъектууд, хувь хүн ба эрдэм шинжилгээний байгууппага, дээд сургууль, судиагааны их сургуупь, хуупийн этгээдийн эрхүүдийг заажээ. Хуупийн дөрөвлүгээр бупэг нь-шинжлэх ухааны салбарын ажилтнуудын нийгмийн хамгаалал, урамшлын асуудлын талаар юм. Шинжлэх ухаан ба шинжлэх ухаантехникийн үйл ажиппагааны удирдлагын зарчмын тухай хуупийн тавдугаар бүлэг зориулагдсан байна. Хуулийн зургадугаар бүпэг нь Шин̆жлэх ухаан, шинжлэх ухааны техникийн үйл ажилпагаагаг санхуүжүулэх зарчмын талаар юм. Шинжлэх ухааныг хөгжүүпэх, эдийн засгаар хөхиүпэн дэмжих, олон улсын хамтын ажиплагааны талаар доплугаар бүпэгт оржээ.

\section{Absract:}

Independence of Khazakstan is an important factor for science and technology development. The scientific organizations of this country by the range of material and technical face, personnel and research, closely reaches the level of leading scientific countries. But the economic change occurred in early 1990 ies badly in fluenced on scientific institutions and science itself. Therefore, reform of science sector was definitely vital issue. This article tells about a detailed information of reform process made in scientific sector during the period of Khazakstan's independance. By making development quality, thus, scientific development of this country approaches the world level.

Key words: Khazakstan, independence, science, development.

\section{ЭШ/ІЭ/, ЗYYIT:}

1Краткая хроника развития науки Казахстана за годы независимости. 06.12.2011 http.element.kz.06.12.2011

$\begin{array}{ll}2 & \text { Мөн тэнд } \\ 3 & \text { Мөн тэнд } \\ \text { 4 } & \text { Мөн тэнд }\end{array}$ 
5 Мөн тэнд

6 Мөн тэнд

7 Мөн тэнд

$8 \mathrm{M \ominus H} \mathrm{тэнД}$

9 Мөн тэнд

${ }^{10} \mathrm{Мөн} \mathrm{тэнд}$

11 Уран бол олон талын шинж чанар бүхий химийн элементуүдийн нэг билээ. Энэхүу эпементийн маш хүчтэй эрчим хүчний эх үүсвэр болохыг анхлан Германы эрдэмтэд олжээ. Тэдний энэ ололтыг Америкийн эрдэмтэд. ургэлжлуүиэн судлаж, атомын зэвсэг бутээв. Энэ уед ЗХУ-д атомын бөмбөг бутээх өөрийн багийг бүрдүүпэн тэдний хэрэгцээтэй түүхий эдээр хангах зорилгоор 3ХУ-ын нутаг дэвсгэр доор ураны нөөцийг ипруүлэн, эрэл хайгуулын ажил явуулахыг зөвшөөрөв. Казахстаны нутагт ч багтав.

12 Байконурын сансрын буудал нь дэлхийн анхных бөгөөд хамгийн том нь юм. 1955 онд байгуупагдсан сансрын буудал нь 6717 км2 гаруй нутгийг эзлэн, хойт талаас өмнө тал хүртэл 76 км, баруунаас зүунээ хүртэл 95 км юм. 1961 онд анх Ю.А.Гагарин эндээс сансрын уудамд нисчээ. Байконурт хөнгөн ("Циклон-М), дунд ("Союз", "Молния", "Зенит"), хунд ("Протон)" болон хамгийн хунд ("Энергия") ангилан зөөгч пуужинг ашиглах ба хөөргөх талбай, дэд бүтэц байрлажээ. Байконур нь сансар судлаль жинтэй хувь нэмэр оруупан, сансар судлалын -"Восток", "Восход", "Салют", "Мир", "Марс", "Венера", "Пуна" болон "Энергия-Буран" төспийг хэрэгжүүпэхэд ашиглав. "Мир"- төслийн хүрээнд 220 байгуулпага, 80-аад эрдэм шинжилгээний байгууплага оролцон "Мир" станцад 104 хун байсны 62 нь гадаадын иргэд байжээ. ЗХУ задарсны дараа Байконур Казахстаны мэдэлд шилжин, ОХУ нь түрээсээр ашиглаж байна. 1957 оноос одоо хуртэл сансарт дэлхий даяр 4000 гаруй зөөгч пуужин хөөргөсний дотор ОХУ-ын 2500 илууг сансарт ипгээсний олонх нь эндээс ниссэн байна. ОХУ-ын Ерөнхийлөгч Путин (2003.04.12) Байконурын сансрын буудал нь бүх талаараа хуучирлаа гээд Казахстаны талтай хамтран ажиллах хэрэгтэйг дурдав.

БНКазУ-ын Ерөнхийлөгчийн зарлигаар 2002 оны 3p сарын 27-нд үндэсний сансар судлалын агентлаг "Казгарыш" байгуулагдав. Сансар судлалын үндсэн зорилт нь аж үйлдвэр инновацийн хөгжлийг хурдасгах, үндэсний аюулгүй байдал болон батпан хамгаалахыг бэхжүулэхэд нөлөө үзуүпэх, эдийн засгийн 
шинжлэх ухааныг хэрэгсдэг болон шинжлэх ухааны нарийн технологийн салбарыг хөгжуүпэхэд чиглэгдсэн байна. "Ирээдүйн эдийн засгийн "гол сапбарын хувьд төрөөс бух талын дэмжлэг авч суүпийн 3 жилд 90 тэрбум тенгээг сансар судпалд зарцуулжээ. "Байконур" сансрын буудлаас сансрын аппаратыг хөөргөхөд оропцох, хүчин чадал болон туршлага хуримтлуулах, дэлхийд тэргүулэх EADS Astriun сансрын компанитай стратегийн хамтын ажиплагаа явуупж байгаа нь сансар судлапын омоохон төслийг хэрэгжүүпэх болопцоо опгож байна. Сансрын аппаратуудыг угсрахтурших цогцолбор босгох, дэлхийг зайнаас тандах (зонд)-сансарын тогтолцоог бий болгох "Байконур" сансрын буудалд экологийн цэвэр "Байтерек" сансрын пуужин хөөргөх цогцопбор байгуулах (уг төсөл нь ОХУ-ын талаас хийх төслийн ажил саатсан, өртөг нь анх төлөвлөснөөс 7 дахин өссөн зэргээс хойшлогдсон) байжээ. Иймээс одоо "Ангара", "Зенит" пуужингийн цогцопбороор сансар судлалыг үргэлжлуупэх ажип хийгдэж байна.

"KazSat"- харипцаа бопон мэдээлэп дамжуупах хиймэп дагуупын тогтопцоог байгуулан, "KazSat-2" хэвийн ажиллаж, 2014 онд "KazSat-3"-ыг ашиглалтанд оруулах ажил хийгдэж байна. "KazSat"- дэпхийн хиймэл дагууплын нөөц газраас удирдах цогцолбор байгуулагджээ. Сансар судпалын сапбарт шинжлэх ухааны судлагаа хийгдэж байна. Сансар судпалын сапбарын судлагааны 23 төслийг хэрэгжүупсэн байна. Эдгээр нь сансрын техник ба технопогийг хийх, ашиглахал зориулан "Казгарыш" үндэсний агентлагийн дэргэд үндэсний сансар суллалын болон технологийн төв байгуупагдав. Туүний бурэлдэхуүнд нэрт эрдэмтэд судалгаа явуупдаг. В.Фесенковын нэрэмжит Астрофризикийн, Ө.Суптангазийн нэрэмжит Сансар судлалын хурээлэн, Ионосферийн хурээлэн, Сансарын техник-технологийн хүрээлэн орж байна.

Сансрын сапбарын мэргэжилтэн бэлтгэхэд ихээхэн анхаардаг байна. Аль-Фарбийн нэрэмжит Казахын үндэсний их сургуупь, П.Гумипевын нэрэмжит Евроазийн их сургуупь, Х.Сатбаевын нэрэмжит Казахын үндэсний техникийн их сургууль, Алматагийн эрчим хүч ба холбооны их сургууль, иргэний нисэхийн академид сансрын чиглэлээр 225 оюутан, Байконур хотын "Восход"Москвагийн нисэхийн академид 205 Казахстаны иргэн сурапцажк байна. Боловсрол ба Шинжлэх ухааны Яамнас жил бур 45 сургалтын грант олгож байна. "Болашак" хөтөлбөрийн хурээнд 22, цалинтай 7 оюутанг сансрын мэргэжилтний чиглэлээр ОХУ, 
- Ирланд, Малайз, АНУ, Их Британид суралцаж байгаа бол 27 хүн сургуупиа төгсч ирж ажилдаа оржээ.

"Казгарыш" нь сансрын техник, технологийг үйлдвэрлэх чиглэлээр дэлхийн тэргуүний улсуудтай хамтын ажиллагааны хөгжүүпэх болжээ. Эдгээр нь ОХУ, Украйн, Франц, ХБНГУ, БНХАУ, Энэтхэг, Их Британи, Итали, Япон, Өмнөд Солонгос, Израйл, Саудын Араб, Нэгдсэн Арабын Эмират юм. Эдгээр сансрын төслуүдийг хэрэгжүүпснээр Казахстаны бүрэн төгс сансрын сапбарыг байгуулах бөгөөд энэ нь эдийн засгийн хүчин зүтгүүр болохын хамт аж үйпдвэрийг хөгжүүпэх, үндэсний аюупгүй байдлыг батлан хамгаалахыг хүчтэй болгоход нөлөөлнө. 